la force armée à des fins internes ou externes), toute formation offerte à des militaires ne devrait jamais perdre de vue que la conduite de la guerre est ce pourquoi les armées existent. Cette vision ne renie pas l'importance d'une solide formation générale; elle suggère simplement de mettre l'accent sur les matières ou les domaines ayant des liens directs avec cette activité humaine qu'est la guerre.

Le lecteur qui aura lu tous les chapitres de ce livre, issu des travaux d'un colloque tenu en mars 2002 au Collège militaire royal du Canada, a un certain mérite : celui de résister à un ensemble assez inégal de textes. Il arrive souvent que cela soit le cas avec les ouvrages collectifs. Il n'est pas facile de regrouper en cinq thèmes plus d'une quinzaine de contributions et d'en faire davantage ressortir les forces que les faiblesses. Les trois codirecteurs de l'ouvrage avaient fort à faire. Par contre, cela n'excuse pas le caractère un peu superficiel ou moins pertinent de certaines contributions qui semblent ne pas avoir été retouchées par leurs auteurs. Leur absence aurait amélioré la qualité de l'ouvrage et certainement permis au lecteur d'avoir une idée moins éclatée de l'éducation militaire au Canada.

Ces remarques n'enlèvent rien à l'une des qualités de cet ouvrage, celle de faire réfléchir sur un sujet mal connu et encore largement à explorer. Pour les initiés et les spécialistes du domaine, il constitue une contribution assez intéressante à la compréhension des multiples défis de l'éducation militaire. Pour le large public, il est une occasion de prendre contact avec une question qui le concerne également et qui risque de devenir dans les prochaines années un sujet d'intérêt public de plus en plus pressant.

Richard Carrier

Collège militaire royal du Canada

Campus Saint-Jean

Thomas C. Dalton. Becoming John Dewey: Dilemmas of a Philosopher and Naturalist. Bloomington, IN: Indiana University Press, 2002. Pp. 377.

In the last fifteen years or so, several biographies of John Dewey (1859-1952) and the intellectual history in which Dewey is a major focus have been published; most notably, James Kloppenberg (1988), Steven C. Rockefeller (1991), Robert Westbrook (1992), John Patrick Diggins (1994), and Alan Ryan (1995). All these books are fascinating historical studies to anyone who is interested in understanding 
Dewey's life and philosophy in such contexts as philosophy, psychology, and educational and social movements. Yet they are so voluminous and packed with information that the mere sight of another biographical study of Dewey may intimidate the reader.

If readers successfully overcome the fear of reading yet another book on Dewey, they should have a look at the title of Thomas Dalton's Becoming John Dewey: Dilemmas of Philosopher and Naturalist, and consider what "naturalist" implies. In fact, this is Dalton's distinctive contribution to the biographical study of Dewey.

Everyone who is even superficially acquainted with Dewey's ideas knows that he thought it crucial to introduce methods of natural sciences into social problems, and that he liked to use the language of science. However, people who are a little more familiar with Dewey also know that he was neither successful nor respected as a scientist. So readers might feel it a bit odd to call Dewey a "naturalist." Dalton argues, however, that Dewey deserves to be called so.

Dalton examines an important, but often overlooked, aspect of Dewey's career. Just like other biographical studies, this book deals with how Dewey became the public figure as we know him: how he left "an insulated academic life" which he spent until his Michigan years (1884-94) and became "a public philosopher" who was interested in and spoke up on various social issues. Unlike other biographies, Dalton takes up a question that nearly everyone seems to have overlooked: how much of a scientist was Dewey? Dewey was more than a mere armchair philosopher or a metaphysician. Biographers of Dewey tell us that Dewey was a social critic, educational innovator, and a person with romance, but Dalton adds that he was also a scientist.

The exposition of Dewey's continuous engagement in scientific research is Dalton's focus and he asks how well informed Dewey actually was on the findings and methods of natural sciences. The answer to the question is, on the surface of it, obvious from the fact that his early text, Psychology (1887), was dismissed by such scientific psychologists of the day as William James and G. Stanley Hall for being merely a metaphysical exposition in scientific disguise. Some readers may recall that Ernest Nagel criticized Dewey in 1954 for relying on "second-hand accounts of scientific research" (p. 248). By meticulously examining Dewey-related documents and following Dewey's personal and professional connections, Dalton argues that he was, at least in later years, thoroughly informed in the latest scientific findings, and actually engaged in scientific experiments. Thus, his naturalism was not merely a façade.

One of Dewey's major sources of information on emerging scientific methods and results was his daughter, Jane Dewey, who studied at the Institute for Theoretical Physics in Copenhagen, directed by Niels Bohr. Jane kept her father informed of her research throughout her stay there (1926-27). However, Dewey's scientific 
interests, particularly in his later years, were in biological, behavioural, and neurological sciences rather than in physics. And as regards Dewey's engagement with science, the upshot is his co-operation with his student, soul-mate, and co-researcher in the 1930s, Myrtle McGraw, and a series of interdisciplinary and experimental studies called "Normal Child Development Study" (NCDS), which McGraw led and in which Dewey, among such other prominent scholars of relevant fields as Edward Thorndike, John Watson, and George Coghill, participated in various capacities. The exposition of the NCDS is the upshot of Dalton's book, and the reader will gain a deeper understanding of the intellectual climate in which Dewey developed his philosophical position and educational ideas. Dalton's account includes how Dewey challenged Freud's conception of the mind and consciousness, and how Dewey and Freud's interests in the origin of the human mind and consciousness converged but the degree of informedness and resulting perspectives diverged (Dalton argues that Dewey was much more up to date on the latest developments in biological research). If a Freudian perspective was a major intellectual backdrop against which Dewey constructed his perspective, another was the nature-nurture controversy. Dewey and McGraw tried to create a new understanding of child development, and Dalton's account of NCDS is particularly informative on this issue.

Through McGraw's research in psychology, Dewey acquainted himself with the latest scientific research and gained a scientific support for his views in such later works as Art as Experience (1934) and Logic (1937). Dalton writes that Dewey and McGraw faced enormous challenges in their respective fields because they were disputing the philosophical and scientific trend of the time. He says, "In their rush to embrace modern science, many philosophers and psychologists purged their discourse of so-called metaphysical terms, such as "mind" and "consciousness," in favor of "stimulus," "response," "association," "perception,” and “conditioning." These were terms that squared with conventional logic" (p. 223). Dewey’s theory of logical or reflective thought, which challenged the conventional view of logical thought (i.e. logical thought proceeds by a step-by-step sequential path from particular to universal), found a scientific underpinning in McGraw's psychological and neurological study. McGraw confronted Gesell's maturationist view of psychomotor development (new functions do not appear until internal maturation of neural structure occurs) as well as Watson's behaviourist view (development is an incremental accumulation of specific functions), and presented a view that growth involves functional leaps that will be integrated into the development of structure later. In this view, Dewey found an analogy and a scientific underpinning that he could use in his theory of logic. Dewey, while appreciating the scientific method and language, did not think it reasonable to dispel such vocabulary as "mind" and "consciousness" as behaviourists did. 
In this sense, as Diggins says, pragmatism "offered the promise that modern man could somehow study the world scientifically and live it spiritually" (The Promise of Pragmatism: Crisis of Knowledge and Authority, University of Chicago Press, 1994, pp. 10-11).

Biographical studies of Dewey seem to be becoming increasingly elaborate on the intellectual, political, and social contexts as well as his personal relationships. Moreover, they are becoming increasingly focused on the contexts of the work of some individuals from whom Dewey borrowed ideas. Dalton's work is no exception; in some places Dewey's figure becomes too weak against such contextual information on various scientific and philosophical ideas, and interpretations of Dewey's ideas.

Dalton's book may not appeal to many readers other than Dewey specialists. Those who are interested in the history of developmental theories but not so keen on the details of Dewey's philosophy and life would not find this book particularly accessible. Having said that, as I suggested earlier, Dalton's work deserves credit for taking up a question which should have occurred to many of Dewey's readers, and yet few took up seriously. For anyone who has had this question, reading this book will be very rewarding. It should be noticed that the book gives a serious account of how speculative philosophy and experimental science played together in the mind of a figure who arguably has the strongest influence on the way we think of philosophy, education, and social issues today in North America. In this sense, Dalton's book is of some use for those who are interested in intellectual history in general and should find a somewhat wider audience beyond Dewey fans.

Keiichi Takaya

Simon Fraser University

\section{Jim Leach and Jeanette Sloniowski, eds. Candid Eyes: Essays on Canadian Documentaries. Toronto: University of Toronto Press, 2003. Pp. 248.}

Very rarely does an academic work come along that speaks as eloquently and as insightfully about film as does Candid Eyes: Essays on Canadian Documentaries. Candid Eyes is a reminder to all cinephiles of Canada's rich documentary heritage. As editors Leach and Sloniowski observe in their opening preface, "documentaries...more than any other form...have continued to be crucial to the formation of Canada's cinematic identity." For students 